\title{
Enhancement quality and quantity of faba bean plants grown under sandy soil conditions by nicotinamide and/or humic acid application
}

Mona Gergis Dawood ${ }^{1 *}$, Yasser Refaai Abdel-Baky ${ }^{1}$, Mohamed El-Sayed El-Awadi ${ }^{1}$ and Gehan Shaker Bakhoum ${ }^{2}$

\begin{abstract}
Background: Two field experiments were conducted at the Research and Production Station, National Research Centre, El-Nubaria Province, El-Behira Governorate, Egypt, during the two successive winter seasons of 2014/2015 and 2015/2016. This work aimed to study the enhancement effect of foliar application of nicotinamide at 5, 10, and $20 \mathrm{mg} / \mathrm{L}$ and/or humic acid at 5\% on quality and quantity of faba bean plants (cultivar Sakha 4) grown under sandy soil conditions.
\end{abstract}

Results: Data show that nicotinamide at 5, 10, and $20 \mathrm{mg} / \mathrm{L}$ and/or humic acid at $5 \%$ had a positive effect on growth parameters, photosynthetic pigments, seed yield, and yield components as well as some biochemical constituents of the yielded faba bean seeds (total carbohydrate, total phenolic content, proline, and free amino acids). Individually, nicotinamide treatments had a more positive effect than humic acid treatment and their effect was increased by increasing nicotinamide concentrations. The most promising treatment appeared due to the interaction between nicotinamide at $10 \mathrm{mg} / \mathrm{L}$ and humic acid. Hence, this treatment increased plant dry weight/plant by $32.67 \%$, total photosynthetic pigments by $113.2 \%$, seed yield/feddan by $110.16 \%$, total carbohydrate by $9.4 \%$, total phenolic content by $0.33 \%$, proline by $24.83 \%$, and free amino acids by $21.33 \%$.

Conclusions: We can conclude that nicotinamide and/or humic acid had a positive effect on growth parameters, photosynthetic pigments, seed yield, and yield components as well as some biochemical constituents of the yielded faba bean seeds. The most promising treatment appeared due to the interaction between nicotinamide at $10 \mathrm{mg} / \mathrm{L}$ and humic acid.

Keywords: Vicia faba, Humic substance, Nicotinamide, Sandy soil

\section{Introduction}

Faba bean (Vicia faba L.) is one of the most important winter legume crops and a major source of protein for both human and animal nutrition (Crepon et al., 2010). Mature seeds of faba bean are good sources of protein (about 25\% in dried seeds), starch, cellulose, vitamin C, and minerals (Hamilton, 2005). They are used for animal feed where, broken seeds are mixed into animal diet and the vegetative parts of the plants are used as the animal

\footnotetext{
*Correspondence: monagergis@yahoo.com

${ }^{1}$ Botany Department, National Research Centre, 33 El Bohooth St. (former El Tahrir St.), Dokki, Cairo 12622, Egypt

Full list of author information is available at the end of the article
}

fodder (Akcin, 1988). At the same time, its cultivation leads to an increase of soil $\mathrm{N}$ compounds (Hungria and Vargas, 2000).

The newly reclaimed sandy soil is mostly exposed to a combination of environmental stress conditions including low water availability, saline water, saline soil, nutrient deprivation, temperature fluctuations, and high irradiances. In winter, when subjected to low temperature during the different stages of growth and development, plants show several biochemical and physiological dysfunctions (Berger et al., 1993). Such disturbances led to a reduction of growth and poor quantity and quality of the yield (Wang, 1982). In this concern, great efforts must be 
paid to increase plant tolerance to such conditions, via selecting tolerant genotypes and applying the optimum cultural practices and/or treating the seeds (before sowing) or plants (at different growth stages) with some growth-regulating substances, that play an important role in helping plants to overcome partially the unfavorable conditions and avoid its negative effects on yield quantity and quality.

Vitamins are required in a trace amount to maintain normal growth and proper development of plant (Bassouny et al., 2008). These compounds act as coenzyme systems and play an essential role in the regulation of metabolism. Therefore, these vitamin supplements are known to enhance plant activities and did not have toxic or mutagenic action (Bronzetti et al., 2001).

Nicotinamide (vitamin B3/niacin) is a water-soluble vitamin and a well-characterized constituent of the pyridine dinucleotide coenzymes NADH and NADPH, which are involved in many enzymatic oxidations--reduction reactions in living cells (Sadak et al., 2010). In addition, nicotinamide is a stress-associated compound that induces and regulates secondary metabolic accumulation and/or the manifestation of defense metabolism in plants (Berglund, 1994; Berglund and Ohlsson, 1995). Nicotinamide is considered as one of the growth-regulating substances which in minute quantities can alter some physiological aspects of plants (Bearder, 1980). Robinson (1973) reported that nicotinamide acts as a coenzyme in the enzymatic reactions by which carbohydrates, fats, and proteins are metabolized and involved in photosynthesis and respiration. Soaking of Pisum sativum L. seeds with nicotinamide at the two dates of sowing significantly increased growth and yield components concomitantly with increases in the amounts of IAA, photosynthetic pigments TSS, free amino acids, proline, and phenolic contents as reported by Sadak (2016). Nicotinamide resulted in a significant improvement of physiological and biochemical parameters as well as the concentrations of soluble sugars, proline, amino acids, and total $N$ and other mineral contents of faba bean plants (Abdelhamid et al., 2013).

The humic substance is formed through the chemical and biological humification of plant and animal matter by the biological activities of microorganisms. These substances influence plant growth directly and indirectly. The indirect effects on soil fertility include (i) the increase in the soil microbial population including beneficial microorganisms, (ii) improved the soil structure, and (iii) the increase in the cation exchange capacity and the $\mathrm{pH}$ buffering capacity of the soil. Regarding direct effects, humic compounds may have various biochemical effects either at cell wall or in the cytoplasm, including increased photosynthesis, respiration rates, enzymatic activities, protein synthesis (Biondi et al., 1994; Nardi et al., 2002), and plant hormone-like activity (Chen and Aviad, 1990). Humic acid is an important component of humic substances that contains many functional groups situated at the carbon chain. They could be acidic (e.g., carboxylic acid and phenol), alkaline (e.g., amine, imines), or neutral groups (e.g., alcohol, aldehyde, ketone, ether, ester, and amide) which improve plant growth (Kadam and Wadje, 2011). Humic acid improves physical (Varanini et al., 1995), chemical, and biological properties of soils (Keeling et al., 2003; Mikkelsen, 2005), controlling soil-borne diseases and improving soil health and nutrient uptake by plants, mineral availability, fruit quality, etc., (Atiyeh et al., 2002; Rahmat et al., 2010; Mauromicale et al., 2011). Moreover, humic acid stimulates plant enzymes/hormones and improve soil fertility in an ecologically and environmentally benign manner (Sarir et al., 2005; Mart, 2007). The hormone-like activities of humic acid in particular auxin, cytokinin, and gibberellins are well documented in various papers (Varanini and Pinton, 2001; Pizzeghello et al., 2002; Chen et al., 2004). When humic acid was added to clay compacted soils, it helps break up clay compacted soils; assists in transferring micronutrients from the soil to the plant; enhances water retention; increases seed germination rates; improves water, air, and root penetration; and stimulates development of microflora population in soils (Mackowiak et al., 2001). When humic acid was applied to sandy soils, it adds essential organic material necessary for water retention, thus improving the root growth and enhancing the sandy soil ability to retain and not leach out vital plant nutrients (Khaled and Fawy, 2011).

This work aimed to study the enhancement effect of the application of nicotinamide and/or humic acid on quality and quantity of faba bean plants grown under sandy soil.

\section{Materials and methods}

\section{Plant materials and experimental conditions}

Two field experiments were conducted at the Research and Production Station, National Research Centre, El-Nubaria Province, El-Behira Governorate, Egypt, during two successive winter seasons of 2014/2015 and 2015/2016. The seeds of faba bean cultivar (Sakha 4) were obtained from the Legumes Crops Research Department, Ministry of Agriculture, Egypt, and selected for uniformity in size and color.

The soil of the experimental site was sandy soil. Mechanical, chemical, and nutritional properties of the experimental soil site (30 depths) were reported in Table 1 and were analyzed according to Chapman and Pratt (1978).

Table 1 Mechanical and chemical analyses of experimental soil

\begin{tabular}{lcclcccccc}
\hline $\begin{array}{l}\text { Sand } \\
(\%)\end{array}$ & $\begin{array}{l}\text { Silt } \\
(\%)\end{array}$ & $\begin{array}{l}\text { Clay } \\
(\%)\end{array}$ & $\begin{array}{l}\text { Soil } \\
\text { texture }\end{array}$ & $\begin{array}{l}\text { PH } \\
\text { ECds/ } \\
\text { m }\end{array}$ & $\begin{array}{l}\text { O.M } \\
(\%)\end{array}$ & $\begin{array}{l}\text { N } \\
\text { ppm }\end{array}$ & $\begin{array}{l}\text { Ppm } \\
\text { Ppm }\end{array}$ \\
\hline 93.7 & 3.9 & 4.78 & Sandy & 7.8 & 0.5 & 0.24 & 9.2 & 3.6 & 23.3 \\
\hline
\end{tabular}


Regarding fertilization, $\mathrm{P}_{2} \mathrm{O}_{5}$ as calcium superphosphate $(15.5 \%)$ and $\mathrm{K}_{2} \mathrm{O}$ as potassium sulfate $(48-52 \%)$ were added during seed bed preparation at the level of 31 and $24 \mathrm{~kg} /$ fed, respectively, while nitrogen fertilizer as ammonium nitrate (33.5\%) was added at the rate of $75 \mathrm{~kg} \mathrm{~N} / \mathrm{fed}$. Seeds of faba bean were sown in hill spaced $20 \mathrm{~cm}$ apart at both sides of the ridge on the middle of November during the two growing seasons. Thinning was carried out at 15 days after sowing to leave two plants per hill. The experiments were laid out in a randomized complete block design with three replicates/treatments. The experimental unit was $10.5 \mathrm{~m}^{2}$ (1/400 fed.) $3-\mathrm{m}$ long and $3.5-\mathrm{m}$ wide, and $60 \mathrm{~cm}$ apart between ridges. The plants were sprayed twice at 45 and 60 days after sowing with freshly prepared solutions of nicotinamide at 5,10 , and $20 \mathrm{mg} / \mathrm{l}$ and humic acid at $5 \%$ individually or in combination. Meanwhile, untreated plants were sprayed by distilled water to serve as a control. Irrigation was carried out using the sprinkler irrigation system where plants were watered every 5 days for $2 \mathrm{~h}$.

\section{Data recorded}

Plant samples were collected after 75 days from sowing for measurement of some growth parameters (plant height, leave and branch number/plant, fresh and dry weights/plant) and photosynthetic pigments in fresh leaf.

At harvest, the following characters, number of pods/ plant, number of seeds/pod, seed yield/plant (g), and 100 seeds weight $(\mathrm{g})$ were recorded at a random of ten guarded plants from each plot. The whole plot was harvested to determine seed yield/feddan $(\mathrm{kg})$. The yielded seeds were cleaned and crushed to determine total carbohydrate, total free amino acid, proline, and total phenolic contents.

\section{Chemical analysis}

Chlorophyll a, chlorophyll b, and carotenoids were determined using a method described by Moran (1982). The phenol-sulfuric acid method was used for the determination of total carbohydrates (Dubois et al., 1956). Total phenolic compounds were determined according to the method described by Zhang and Wang (2001). Proline was estimated according to Bates et al. (1973). Free amino acid content was determined with the ninhydrin reagent method (Yemm and Cocking, 1955).

\section{Statistical analysis}

The average of two seasons was statistically analyzed as a randomized complete block design according to Snedecor and Cochran (1980), and the least significant difference (L.S.D.) for each was calculated at 0.05 level of probability by using the MSTATC (1989) program in this connection.

\section{Results \\ Vegetative growth parameters}

Table 2 showed that nicotinamide and/or humic acid application caused marked increases in plant height, number of branches and leaves/plant, and fresh and dry weight/plant. These parameters were increased gradually by increasing nicotinamide concentration. Moreover, data indicated that nicotinamide treatments individually were more effective than humic acid. On the other hand, it was noted that interaction between nicotinamide at $10 \mathrm{mg} / \mathrm{L}$ and humic acid caused the highest significant increases of all vegetative growth parameters relative to control. Hence, this treatment increased plant dry weight/plant by $32.67 \%$ over control.

Table 2 Effect of nicotinamide and/or humic acid on vegetative growth parameters of faba bean plants at 75 days after sowing (data are combined of two seasons)

\begin{tabular}{|c|c|c|c|c|c|}
\hline Treatments & $\begin{array}{l}\text { Plant height } \\
(\mathrm{cm})\end{array}$ & $\begin{array}{l}\text { Number of branches/ } \\
\text { plant }\end{array}$ & $\begin{array}{l}\text { Number of leaves/ } \\
\text { plant }\end{array}$ & $\begin{array}{l}\text { Plant fresh weight } \\
\text { (g) }\end{array}$ & $\begin{array}{l}\text { Plant dry weight } \\
\text { (g) }\end{array}$ \\
\hline Control & 34.00 & 2.33 & 19.83 & 35.39 & 9.91 \\
\hline Humic acid 5\% & 36.50 & 2.33 & 21.50 & 40.63 & 10.82 \\
\hline Nicotinamide $5 \mathrm{mg} / \mathrm{L}$ & 37.50 & 2.66 & 22.50 & 43.30 & 11.10 \\
\hline Nicotinamide $10 \mathrm{mg} / \mathrm{L}$ & 38.00 & 2.83 & 23.00 & 44.35 & 12.60 \\
\hline Nicotinamide 20 mg/L & 38.50 & 2.83 & 24.67 & 46.85 & 13.38 \\
\hline $\begin{array}{l}\text { Nicotinamide } 5 \mathrm{mg} / \mathrm{L}+\text { humic acid } \\
5 \%\end{array}$ & 37.00 & 2.33 & 23.17 & 37.74 & 11.20 \\
\hline $\begin{array}{l}\text { Nicotinamide } 10 \mathrm{mg} / \mathrm{L}+\text { humic acid } \\
5 \%\end{array}$ & 38.00 & 3.00 & 29.17 & 51.46 & 14.05 \\
\hline $\begin{array}{l}\text { Nicotinamide } 20 \mathrm{mg} / \mathrm{L}+\text { humic acid } \\
5 \%\end{array}$ & 37.50 & 2.33 & 22.83 & 37.85 & 10.59 \\
\hline L.S.D. at $5 \%$ & 3.28 & N.S & 6.19 & 3.13 & 1.51 \\
\hline
\end{tabular}


Table 3 Effect of nicotinamide and/or humic acid on photosynthetic pigments ( $\mathrm{mg} / \mathrm{g}$ ) of fresh faba bean leaf at 75 days after sowing

\begin{tabular}{|c|c|c|c|c|c|}
\hline Treatments & Chlorophyll a & Chlorophyll b & Carotenoid & Chlorophyll $\mathrm{a}+$ chlorophyll b & $\begin{array}{l}\text { Total photosynthetic } \\
\text { pigments }\end{array}$ \\
\hline Control & 1.464 & 0.399 & 0.062 & 1.863 & 1.925 \\
\hline Humic acid 5\% & 1.574 & 0.541 & 0.281 & 2.115 & 2.396 \\
\hline Nicotinamide $5 \mathrm{mg} / \mathrm{L}$ & 1.702 & 0.878 & 0.207 & 2.580 & 2.787 \\
\hline Nicotinamide $10 \mathrm{mg} / \mathrm{L}$ & 1.925 & 1.104 & 0.207 & 3.029 & 3.236 \\
\hline Nicotinamide $20 \mathrm{mg} / \mathrm{L}$ & 1.838 & 1.339 & 0.168 & 3.177 & 3.345 \\
\hline Nicotinamide $5 \mathrm{mg} / \mathrm{L}+$ humic acid $5 \%$ & 1.567 & 0.734 & 0.155 & 2.301 & 2.456 \\
\hline Nicotinamide $10 \mathrm{mg} / \mathrm{L}+$ humic acid 5\% & 2.167 & 1.668 & 0.270 & 3.835 & 4.105 \\
\hline Nicotinamide 20 mg/L + humic acid 5\% & 2.043 & 1.296 & 0.143 & 3.339 & 3.482 \\
\hline L.S.D. at $5 \%$ & 0.42 & 0.71 & 0.10 & 1.03 & 0.94 \\
\hline
\end{tabular}

\section{Photosynthetic pigments}

All applied treatments caused marked increases in all components of photosynthetic pigments (chlorophyll a, chlorophyll b, carotenoids) (Table 3). Regarding nicotinamide treatments, it was notated that plant photosynthetic pigments were increased by increasing nicotinamide concentration, whereas the interaction between nicotinamide at $10 \mathrm{mg} / \mathrm{L}$ and humic acid caused the highest significant increases in total photosynthetic pigments relative to other treatments. Hence, it increased the total photosynthetic pigments by $113.2 \%$ over control.

\section{Seed yield and yield components}

Nicotinamide and/or humic acid treatments caused obvious increases of pod number/plant, seed number/pod, weight of 100 seeds, seed yield/plant, and seed yield/feddan relative to control (Table 4). Nicotinamide application individually at different concentration increased seed yield and its components relative to control by increasing nicotinamide concentrations. The interaction between nicotinamide at $10 \mathrm{mg} / \mathrm{L}$ and humic acid showed the maximum increases in seed components and seed yield. Hence, this treatment increased seed yield/feddan by $110.16 \%$ relative to control.

\section{Some biochemical constituents of the yielded seeds}

All concentration of nicotinamide and humic acid individually or in combination caused significant increases in carbohydrate content, total phenolic content, proline, and free amino acids relative to control (Table 5). The interaction between nicotinamide at $10 \mathrm{mg} / \mathrm{L}$ and humic acid increased carbohydrate, phenolic, proline, and free amino acid contents by $9.40 \%, 0.33 \%, 24.33 \%$, and $21.33 \%$, respectively, relative to control.

\section{Discussion}

\section{Vegetative growth parameters}

Table 2 shows that nicotinamide and/or humic acid application caused marked increases in shoot height, number of branches and leaves/plant, and fresh and dry weight/plant. On the other hand, it was noted that interaction between nicotinamide at $10 \mathrm{mg} / \mathrm{L}$ and humic acid

Table 4 Effect of nicotinamide and/or humic acid on seed yield and yield components of faba bean plants

\begin{tabular}{|c|c|c|c|c|c|}
\hline Treatments & $\begin{array}{l}\text { Number of pods/ } \\
\text { plant }\end{array}$ & $\begin{array}{l}\text { Number of seeds/ } \\
\text { pod }\end{array}$ & $\begin{array}{l}\text { Weight of seeds/plant } \\
\text { (g) }\end{array}$ & $\begin{array}{l}\text { Weight of } 100 \text { seeds } \\
\text { (g) }\end{array}$ & $\begin{array}{l}\text { Seed yield (kg/ } \\
\text { feddan) }\end{array}$ \\
\hline Control & 10.00 & 3.00 & 25.77 & 70.30 & 346.30 \\
\hline Humic acid 5\% & 10.17 & 3.33 & 26.80 & 70.50 & 360.50 \\
\hline Nicotinamide $5 \mathrm{mg} / \mathrm{L}$ & 13.33 & 3.33 & 37.77 & 74.43 & 507.70 \\
\hline Nicotinamide $10 \mathrm{mg} / \mathrm{L}$ & 14.00 & 3.50 & 39.70 & 78.20 & 528.60 \\
\hline Nicotinamide 20 mg/L & 16.00 & 3.50 & 46.00 & 83.10 & 618.30 \\
\hline $\begin{array}{l}\text { Nicotinamide } 5 \mathrm{mg} / \mathrm{L}+\text { humic acid } \\
5 \%\end{array}$ & 14.00 & 3.33 & 39.57 & 78.63 & 532.10 \\
\hline $\begin{array}{l}\text { Nicotinamide } 10 \mathrm{mg} / \mathrm{L}+\text { humic } \\
\text { acid } 5 \%\end{array}$ & 17.17 & 3.50 & 54.13 & 88.73 & 727.80 \\
\hline $\begin{array}{l}\text { Nicotinamide } 20 \mathrm{mg} / \mathrm{L}+\text { humic } \\
\text { acid } 5 \%\end{array}$ & 10.33 & 3.17 & 27.03 & 78.47 & 362.90 \\
\hline L.S.D. at $5 \%$ & 1.131 & N.S. & 2.93 & 5.44 & 103.70 \\
\hline
\end{tabular}


Table 5 Effect of nicotinamide and/or humic acid on some biochemical constituents of the yielded faba bean seeds

\begin{tabular}{lllll}
\hline Treatments & Total carbohydrate $(\%)$ & Total phenolic content $(\mathrm{mg} / \mathrm{g})$ & Proline $(\mathrm{mg} / \mathrm{g})$ & Free amino acids $(\mathrm{mg} / \mathrm{g})$ \\
\hline Control & 39.98 & 18.51 & 27.86 & 118.00 \\
Humic acid 5\% & 42.15 & 24.20 & 32.26 & 129.60 \\
Nicotinamide $5 \mathrm{mg} / \mathrm{L}$ & 41.54 & 21.92 & 26.90 & 125.10 \\
Nicotinamide $10 \mathrm{mg} / \mathrm{L}$ & 41.67 & 22.93 & 31.38 & 131.80 \\
Nicotinamide $20 \mathrm{mg} / \mathrm{L}$ & 42.44 & 24.08 & 33.11 & 136.30 \\
Nicotinamide $5 \mathrm{mg} / \mathrm{L}+$ humic acid 5\% & 42.60 & 23.08 & 31.95 & 130.60 \\
Nicotinamide $10 \mathrm{mg} / \mathrm{L}+$ humic acid 5\% & 43.74 & 24.66 & 34.78 & 158.10 \\
Nicotinamide $20 \mathrm{mg} / \mathrm{L}+$ humic acid 5\% & 41.40 & 23.19 & 31.50 & 143.60 \\
L.S.D. at 5\% & 1.34 & 0.85 & 0.69 & 6.17 \\
\hline
\end{tabular}

caused the highest significant increases of all vegetative growth parameters relative to control. The stimulatory effects of nicotinamide on plant growth were found to be correlated with the increase in content and activity levels of endogenous promoters (Kumari et al., 1987; Wilkins, 1989). Nicotinamide is known as a growthregulating factor that influences many physiological processes such as biosynthesis of enzymes, nucleic acids, and proteins and acts as a coenzyme (Hathout, 1995). These results are in agreement with those obtained by others Zhang et al. (2000), El-Bassiouny et al. (2005), Hassanein et al. (2009), Sadak et al. (2010), and Erdal et al. (2011).

On the other hand, Karakurt et al. (2009), El-Nemr et al. (2012), and Said-Al Ahl et al. (2016) showed that foliar spray of humic acid enhanced plant growth, yield, and quality in a number of plant species due to its action on different physiological and metabolic processes. Humic acid increased nutrient absorption, cell division, photosynthesis (Atiyeh et al., 2002), respiration, biosynthesis of nucleic acid and enzyme, and overall, dry weight of the plant (Ulukan, 2008; Said-Al Ahl et al., 2016). Moreover, application of humic acid to foliage and to soil increased auxin, cytokinin, and gibberellin levels in plants (Abdel-Mawgoud et al., 2007). Likewise, humic acid is a hormone-like substance, its auxin-like activity stimulated the cell division and cell elongation (Mato et al., 1971; Schnitzer and Weightman, 1974), and this in turn improved plant growth (Abdel-Mawgoud et al., 2007). Furthermore, El-Ghozoli (2003) and Meganid et al. (2015) confirmed that humic acid was able to produce positive effects in improving fresh and dry biomass of faba bean and common bean plants.

\section{Photosynthetic pigments}

All applied treatments caused marked increases in all components of photosynthetic pigments (chlorophyll a, chlorophyll b, carotenoids) (Table 3). The enhancement effect of nicotinamide on photosynthetic pigments is confirmed by Sadak et al. (2010) and Abdelhamid et al.
(2013) on sunflower and faba bean. Nicotinamide might be protecting chloroplast and their membrane and maintaining their integrity and protect chloroplast from oxidative damage (Taylor et al., 1982; Munne-Bosch et al., 2001). In addition, the effect of nicotinamide on the biosynthesis of chlorophyll might be attributed to its activation of enzymes that regulate photosynthetic carbon reduction (Taylor et al., 1982). On the other hand, the positive effect of humic acid on photosynthetic pigments could be attributed to an increased in $\mathrm{CO}_{2}$ assimilation and photosynthetic rate (Ameri and Tehranifar, 2012). These increases might be due to the role of humic acid in increasing rubisco enzyme activity and then increased the photosynthetic activity of plants and its yield (Delfine et al., 2005). Humic acid might be caused an enhancement in the synthesis of the chlorophyll and/or delayed chlorophyll degradation even under different stress as reported by Nardi et al. (2002) and Meganid et al. (2015). The increases in photosynthetic pigment content were due to the humic acid application in agreement with those obtained by Ameri and Tehranifar (2012), Bakry et al. (2013), and El-Bassiouny et al. (2014) on different plants.

\section{Seed yield and yield components}

Nicotinamide and/or humic acid treatments caused obvious increases of the pod number/plant, seeds number/pod, weight of 100 seeds, seed yield/plant, and seed yield/feddan relative to control (Table 4). The increase in seed yield and yield components due to nicotinamide treatments might be attributed to the effect of vitamins on enhancing protein synthesis and delaying senescence (Sahu et al., 1993). On the other hand, Srivastava (1995) stated that humic acid application increased photosynthetic rate, nutrient uptake from the soil to leaves, and translocation of these nutrients from the leaves to seeds, thereby enhancing seed yield without spending any energy as well as without any loss in transit. Humate treatment enhanced overall metabolism of crop plants and overall photosynthetic rate and hence the yield in general (Zeng, 2002). Moreover, Moraditochaee (2012) 
recommended that humic acid significantly increased seed yield, straw yield, and biological yield of peanut. Many researchers concluded the enhancing effect of humic acid on growth, yield, and nutrient uptake by many crops (Neri et al., 2002; El-Desuki, 2004; Saruhan et al., 2011).

\section{Some biochemical constituents of the yielded seeds}

All concentration of nicotinamide and humic acid individually or in combination caused significant increases in carbohydrate content, total phenolic content, proline, and free amino acids relative to control (Table 5). These results could be explained by several authors, i.e., Robinson (1973) who revealed that nicotinamide acts as a coenzyme in the enzymatic reactions of carbohydrates, fats, and protein metabolism and involved in photosynthesis and respiration. Tarraf et al. (1999) reported that foliar application of nicotinamide to lemon grass plants significantly increased total carbohydrate and crude protein. Moreover, Sana and Ota (1977), Bearder (1980), and Hathout et al. (1993) reported that nicotinamide plays an important role in increasing pigments, carbohydrates, nitrogen, RNA, and DNA contents in plants. Mohamed et al. (1989) and Sadak et al. (2010) found that nicotinamide increased the level of carbohydrates of wheat and sunflower plant. These results are in agreement with those obtained by Hassanein et al. (2009) in maize and Sadak et al. (2010) in sunflower plant.

On the other hand, Ferrara and Brunetti (2010) observed the positive effect of HA on the photosynthetic metabolism in berry leaves, accompanied by an increase of soluble sugars and this change appeared to be mediated by variations of the activity of the main enzymes involved in carbohydrate metabolism (Merlo et al., 1991).

Regarding phenolic contents, total phenolic contents play a significant mechanism in the regulation of plant metabolic processes and consequently of overall plant growth (Lewis and Yamamoto, 1990). Moreover, phenolic contents act as a substrate for many antioxidant enzymes, so, it mitigates stress injuries (Khattab, 2007). Unlu et al. (2010) showed that humic acid application significantly improved antioxidant compounds in pepper fruit and this effect was mainly on carotenoids and phenolic compounds.

In respect to proline, total amino acids, and the treatment with humic acid and/or nicotinamide increased significantly free amino acid contents and proline of faba bean sees when compared with control. These obtained results are in agreement with those obtained by Peymaninia et al. (2012) on wheat, Bakry et al. (2013) on flax, and El-Bassiouny et al. (2014) on the wheat plant.

Many functions have been postulated for proline accumulation in plant tissues, and proline and free amino acids could be involved in the osmotic adjustment of plants (Delavari et al., 2010) and could also be a protective agent of enzymes and membranes (Gzik, 1996). When a plant is subjected to unfavorable conditions as the newly reclaimed sandy soil, plants maintain their water content by the accumulation of compatible organic solutes acting as osmoprotectants, as proline, in their cytoplasm (Bandurska, 1993). This means that the inhibitory effect of unfavorable conditions on faba bean plant was alleviated by nicotinamide and/or humic acid treatments through increasing proline synthesis and/or enhancing the biosynthesis of other amino acids and their incorporation into protein. Barakat (2003) stated that vitamins probably improve growth of plants and attributed to inhibiting proline synthesis and/or enhancing the biosynthesis of other free amino acids and their incorporation into protein. In addition, vitamins might act as activators of protein synthesis via significant alteration in the enzymes related to protein metabolism (Kodandaramaiah, 1983). Humic acid influences the respiration process, the amount of sugars, amino acids, and nitrate accumulated (Boehme et al., 2005).

\section{Conclusion}

It could be concluded that nicotinamide at 5, 10, and $20 \mathrm{mg} / \mathrm{l}$ and/or humic acid at $5 \%$ showed a positive effect on growth parameters, photosynthetic pigments, seed yield, and yield components as well as some biochemical constituents of the yielded faba bean seeds (total carbohydrate, total phenolic content, proline, and free amino acids). The most promising treatment was appeared due to the interaction between nicotinamide at $10 \mathrm{mg} / \mathrm{L}$ and humic acid.

Acknowledgements

Not applicable

Funding

No Funding

Availability of data and materials

Not applicable

Authors' contributions

All authors contributed to this work and read and approved the final manuscript.

Ethics approval and consent to participate

Not applicable

Consent for publication

Not applicable

Competing interests

The authors declare that they have no competing interests".

\section{Publisher's Note}

Springer Nature remains neutral with regard to jurisdictional claims in published maps and institutional affiliations.

Author details

${ }^{1}$ Botany Department, National Research Centre, 33 El Bohooth St. (former El Tahrir St.), Dokki, Cairo 12622, Egypt. ${ }^{2}$ Field Crops Department, National 
Research Centre, 33 El Bohooth St. (former El Tahrir St.), Dokki, Cairo 12622, Egypt.

\section{Received: 25 October 2018 Accepted: 4 February 2019} Published online: 14 February 2019

\section{References}

Abdelhamid MT, Sadak MSH, Schmidhalter URS, EL-Saady M (2013) Interactive effects of salinity stress and nicotinamide on physiological and biochemical parameters on faba bean plant. Acta Biológica Colombiana 18(3):499-510

Abdel-Mawgoud AMR, El-Greudy NHM, Helmy YI, Singer SM (2007) Responses of tomato plants to different rates of humic based fertilizer and NPK fertilization. J Appl Sci Res 3(2):169-174

Akcin, A. Ediable grain legumes. University of Seluk, College of Agriculture. Publication Number (8) Konya (in Turkish). 1988

Ameri A, Tehranifar A (2012) Effect of humic acid on nutrient uptake and physiological characteristic Fragaria x AnanassaVar: Camarosa. J Biol Env Sci 6:77-79

Atiyeh RM, Edwards CA, Metzger JD, Lee S, Arancon NQ (2002) The influence of humic acids derived from earth warm-processed organic wastes on plant growth. Bioresour Technol 84:7-14

Bakry AB, Sadak MS, Moamen HT, Abd El Lateef EM (2013) Influence of humic acid and organic fertilizer on growth, chemical constituents, yield and quality of two flax seed cultivars grown under newly reclaimed sandy soils. Int $」$ Acad Res 5(5):125-134

Bandurska H (1993) In vitro and in vivo effect of proline on nitrate reductase activity under osmotic stress in barley. Acta Physiol Plant 15:83-88

Barakat H (2003) Interactive effects of salinity and certain vitamins on gene expression and cell division. Int J Agric Biol 5(3):219-225

Bassouny FM, Hassanein RA, Baraka DM, Khalil RR (2008) Physiological effects of nicotinamide and ascorbic acid on Zea mays plant grown under salinity stress. II-Changes in nitrogen constituents, protein profiles, protease enzymes and certain inorganic cations. Aust J Basic Appl Sci 2(3):350-359

Bates LS, Waldan RP, Teare LD (1973) Rapid determination of free proline under water stress studies. Plant Soil 39:205-207

Bearder IR (1980) Plant hormones and other background, structure and occurrence, 9-112. In: mac Millan J (ed) Hormonal regulation and development. Encyclopedia of plant physiology. New series, vol 9. Springer Verlag, Berlin, Heidelberg. New York, USA

Berger S, Ellersiek U, Westoff P, Steinmuller K (1993) Studies on the expression of $\mathrm{NDH}-\mathrm{H}$, a subunit of the NAD (P)H-plastoquinone oxidoreductase of higher plant chloroplasts. Planta 190:25-31

Berglund T (1994) Nicotinamide, a missing link in the early stress response in eukaryotic cells: a hypothesis with special reference to oxidative stress in plants. FEPS Letters 351(2):375-383

Berglund T, Ohlsson AB (1995) Defensive and secondary metabolism in plant tissue cultures, with special reference to nicotinamide, glutathione and oxidative stress. Plant Cell Tiss Organ Cult 43:137-145

Biondi FA, Figholia A, Indiati R, Izza C (1994) Effects of fertilization with humic acids on soil and plant metabolism: a multidisciplinary approach. Notelll: phosphorus dynamics and behaviour of some plant enzymatic activities. In: Senesi N, Miano TM (eds) Humic substances in the global environment and implications on human health. Elsevier, New York, pp 239-244

Boehme, M., Schevtschenko, J., Pinker I. 2005. Iron supply of cucumbers in substrate culture with humate. Acta Horticulturae 697 ISHS 41(1): 329-335

Bronzetti, G., Cini, M., Andreoli, E., Caltavuturo, L., Panunzio, M., Croce, C.D. 2001. Protective effects of vitamins and selenium compounds in yeast. Mutation Research496: 105-15

Chapman HD, Pratt PF (1978). Methods of Analysis for Soils, Plants and Waters. Univ. California Div. Agric. Sci. Priced Publication.

Chen, Y, Aviad, T. 1990. Effects of humic substance on plant growth. In MacCarthy, CE Clapp, RL Malcolm, PR bloom (eds.). Humic substances in soil and crop sciences: selected readings. Soil Sci. Society of America. Madison. Wisconsin. Pp. 161-186

Chen, Y., De Nobili, M.,Aviad, T. 2004. Stimulatory effects of humic substances on plant growth. In: Soil organic matter in sustainable agriculture (Magdoff F., Weil R.R., eds). CRC Press, NY, USA. pp. 103-129

Crepon K, Marget P, Peyronnet C, Carrouée B, Arese P, Duc G (2010) Nutritional value of faba bean (Vicia faba L.) seeds for feed and food. Field Crop Res 115:329-339
Delavari PM, Baghizadeh A, Enteshari SH, Kalantari KHM, Yazdanpanah A, Mousavi EA (2010) The effects of salicylic acid on some of biochemical and morphological characteristic of Ocimum basilicucm under salinity stress. Aust J Basic Appl Sci 4:4832-4845

Delfine S, Tognetti R, Desiderio E, Alvino A (2005) Effect of foliar application of N and humic acids on growth and yield of durum wheat. Agron Sustain Dev 25:183-191

Dubois, M., Gilles K.A.Hamilton, J.K., Robers P.A. 1956. Colourimetric method for determination of sugars and related substances. Analytical Chemistry 28: 350-356

El-Bassiouny HMS (2005) Physiological responses of wheat to salinity alleviation by nicotinamide and tryptophan. Int J Agric Biology 7:653-659

El-Bassiouny HSM, Bakry AB, Abd El-Monem AA, Abd Allah MM (2014) Physiological role of humic acid and nicotinamide on improving plant growth, yield, and mineral nutrient of wheat (Triticum durum) grown under newly reclaimed sandy soil. Agric Sci 5:687-700

El-Desuki M (2004) Response of onion plants to humic acid and mineral fertilizers application. Annl Agric Sci 42(4):1955-1964

EL-Ghozoli, A.A.2003. Influence of humic acid on faba bean plants grown in cadmium polluted soil. Annals of Agricultural Sciences, Moshtohor 41(4): 1787-1800

El-Nemr MA, El-Desuki M, El-Bassiony AM, Fawzi ZF (2012) Response of growth and yield of cucumber plants (Cucumissativus L.) to different foliar application of humic acid and bio-stimulators. Aust J Basic Appl Sci 6(3):630-637

Erdal S, Aydın M, Genisel M, Taspınar MS, Dumlupinar R, Kaya O, Gorcek Z (2011) Effects of salicylic acid on wheat salt sensitivity. Afr J Biotechnol 10:5713-5718

Ferrara G, Brunetti G (2010) Effects of the times of application of a soil humic acid on berry quality of table grape (Vitis vinifera L.) cv Italia. Span J Agric Res 8:817-822

Gzik A (1996) Accumulation of proline and pattern of a-amino acids in sugar beet plants in response to osmotic, water and salt stress. Environ Exp Bot 36:29-38

Ibrahim ME, Bekheta MA, El-Moursi A, Gaafar NAC (2007). Improvement of growth and seed yield quality of Vicia faba L. plants as affected by application of some bioregulators. Aust J Basic Appl Sci 1(4): 657-66

Hassanein RA, Bassony FM, Barakat DM, Khalil RR (2009) Physiological effects of nicotinamide and ascorbic acid on Zea mays plant grown under salinity stress. I - changes in growth, some relevant metabolic activities and oxidative defense systems. Res J Agric Biol Sci 5(1):72-80

Hathout TA (1995) Diverse effects of uniconazole and nicotinamide on germination, growth, endogenous hormones and some enzymic activities of peas. Egypt J Physiol Sci 19:77-95

Hathout TA, Shetawi SA, Khallal SM (1993) Mode of application of some growth regulators on physiology of tomato. III. Effect of nicotineamide on morphology, growth, metabolism and productivity. Egypt J Physiol Sci 17(2):183-200

Hungria M, Vargas MAT (2000) Environmental factors affecting N2 fixation in grain legumes in the tropics, with an emphasis on Brazil. Field Crop Res 65:151-164

Kadam AS, Wadje SS (2011) Role of potassium humate on growth and yield of soybean and black grAM. Int J Pharm Bio Sci 2(1):242-246

Karakurt Y, Unlu H, Padem H (2009) The influence of foliar and soil fertilization of humic acid on yield and quality of pepper. Acta Agric Scand Sect B Plant Soil Sci 59(3):233-237

Keeling AA, McCallum KR, Beckwith CP (2003) Crop and Environment Research Centre, Harper Adams University College, Newport, Shropshire, UK. Bioresour Technol 90(2):127-137

Khaled H, Fawy HA (2011) Effect of different levels of humic acids on the nutrient content, plant growth, and soil properties under conditions of salinity. Soil Water Resour 6(1):21-29

Khattab H (2007) Role of glutathione and polyadenylic acid on the oxidative defense systems of two different cultivars of canola seedlings grown under saline condition. Aust J Basic Appl Sci 1:323-334

Kodandaramaiah, J. 1983. Physiological studies on the influence of B-vitamins on leaf and fruit metabolism in cluster beans Cyamopsis tetagonoloba L. Tanb. Ph.D. Thesis, SrivenkatesweraUniversity, Tirupati, India

Kumari R, Verma KK, Dhindsa KS, Bhatti DS (1987) Screening aerial parts of Datura, Ipomoea, tagests and Lawsonia for their nematicidal activity on MeloidogyneJavancia. Agric Sci Dig 7(4):213

Lewis N, Yamamoto E (1990) Lignin: occurrence, biogenesis and biodegradation. Annu Rev Plant Physiol Plant Mol Biol 41:455-496

Mackowiak CL, Grossl PR, Bugbee BG (2001) Beneficial effect of humic acid on micronutrients availability to wheat. Soil Sci Soc of Am J 2001(65):1744-1751 
Mart, I. 2007. Fertilizers, organic fertilizers, plant and agricultural fertilizers. Agro and Food Business Newsletter pp. i-iv

Mato, M.C., Fabregas R., Mendez, J.1971. Inhibitory effect of soil humic acids on indoleacetic acid oxidase. Soil Biology and Biochemistry3: 285-288

Mauromicale G, Angela MGL, Monaco AL (2011) The effect of organic supplementation of solarized soil on the quality of tomato. Sci Hortic 129(2):189-196

Meganid AS, Al-Zahrani HS, EL-Metwally MS (2015) Effect of humic acid application on growth and chlorophyll contents of common bean plants (Phaseolus vulgaris L.) under salinity stress conditions. Int J Inn Res Sci Eng Technol 4(5):2651-2660

Merlo L, Ghisi R, Rascio N, Passera C (1991) Effects of humic substances on carbohydrate metabolism of maize leaves. Can J Plant Sci 71:419-425

Mikkelsen, R.L. 2005. Humic materials for agriculture, Davis, California, USA. Better Crops with Plant Food 89 (3): 6-7

Mohamed, Y.A.H., Sharf El-Din, A., Foda, E. 1989. Role of nicotinamide and salicylaldehyde on some growth parameters in wheat. Phyton 29: 33-41

Moraditochaee M (2012) Effect of humic acid foliar spraying and nitrogen fertilizer management on yield of peanut (Arachis hypogaea L.) in Iran. J Agric Biol Sci 7:289-293

Moran R (1982) Formula for determination of chlorophyllous pigments extracted with N,N-dimethylformamide. Plant Physiol 69:1371-1381

MSTATC (1989) A microcomputer program for the design management and analysis of agronomic research experiments. Michigan State Univ, U.S.A.

Munne-Bosch S, Schwarz K, Algere L (2001) Water deficit in combination with high solar radiation leads to midday depression of a-tocopherol in field grown lavender (Lavandulastoechas) plants. Aust J Plant Physiol 28:315-321

Nardi S, Pizzeghello D, Muscolo A, Vianello A (2002) Physiological effects of humic substances in plant growth. Soil Biol Biochemistry 34(11):1527-1536

Neri, D., Lodolini, E.M.,Savini, G.Sabbatini, P.,Bonanomi, G.ZZucconi, F. 2002. Foliar application of humic acid on strawberry (cv. Onda). Proceeding $1 \mathrm{~S}$ on foliar nutrient. Eds. M. Tagliavini et al. ActaHorticulturae 594: 297-302

Peymaninia Y, Valizadeh M, Shahryari R, Ahmadizadeh M, Habibpour M (2012) Relationship among morpho-physiological traits in bread wheat against drough stress at presence of a leonardite derived humic fertilizer under greenhouse condition. Int Res J Appl Basic Sci 3:822-830

Pizzeghello D, Nicolini G, Nardi S (2002) Hormone-like activities of humic substances in different forest ecosystems. New Phytol 155:393-402

Rahmat UKA, Rashid MS, Ozturk KE (2010) Impact of humic acid and chemical fertilizer application on growth and grain yield of rainfed wheat (Truticumaestivum, L.). Pak J Agric Sci 23(3-4):113-121

Robinson FA (1973) Vitamins. In: Miller LP (ed) Phytochemistry, vol 3. Van-Nostrand Reinhold Co, New York

Sadak MS (2016) Physiological role of yeast extract and nicotinamide on Pisumsativum L. plants under heat stress. Int J PharmTech Res 9(9):170-178

Sadak MS, Rady M, Badr NM, Gaballah MS (2010) Increasing sunflower salt tolerance using nicotinamide and a-tocopherol. Int J Acad Res 2(4):263-270

Sahu MP, Solanki NS, Dashora LN (1993) Effects of thiourea, thiamine and ascorbic acid on growth yield of maize (Zea mays L.). J Agric Crop Res 117(1):65-69

Said-AIAhI HAH, El Gendy AG, Omer EA (2016) Humic acid and indole acetic acid affect yield and essential oil of dill grown under two different locations in Egypt. J Pharm Sci Res 8(8):146-157

Sana IS, Ota Y (1977) Plant growth regulating activities of nicotinamide. II. Effect of nicotinamide on growth of several crops. Jap J Crop Sci 46:8

Sarir MS, Sharif M, Ahmed Z, Akhlaq M (2005) Influence of different levels of humic acid application by various methods on the yield and yield components of maize. Sarhad J Agric 21(1):75-81

Saruhan V, Kuvuran A, Babat S (2011) The effect of different humic acid fertilization on yield and yield components performances of common millet (Panicummiliaceum L.). Sci Res Essays 6(3):663-669

Schnitzer EA, Wightman F (1974) Metabolism of auxin in higher plants. Annu Rev Plant Physiol 25:487-513

Snedecor, G.W., Cochran, W.G. 1980. Statistical methods 7th edition. lowa State Univ., Press Ames, lowa, U.S.A

Srivastava HN (1995) Mineral nutrition, plant physiology, 7th edn. Pradeep Publications, Jalandhar, p 137

Tarraf, Sh.A., Gamal El-Din, K.M.,Balbaa, L.K. 1999. The response of vegetative growth, essential oil of lemongrass (Cymbopogon citrates, Hort) to foliar application of ascorbic acid, nicotinamide and some micronutrients. Arab University Journal of Agriculture Science, Ain Shams University 7(1): 247-259
Taylor SE, Terry N, Huston RP (1982) Limiting factors in photosynthesis. Plant Physiol 10:1541-1543

Ulukan H (2008) Effect of soil applied humic acid at different sowing times on some yield components in wheat (Triticum spp.) hybrids. Int J Bot 4:164-175

Unlu H, Unlu HO, Karakurt Y (2010) Influence of humic acid on the antioxidant compounds in pepper fruit. Food Agric Environ 8:434-438

Varanini, Z., Pinton, R. 2001. Direct versus indirect effects of soil humic substances on plant growth and nutrition. In: the rhizosphere: biochemistry and organic substances at the soil-plant interface (Pinton R., Varanini Z., Nannipieri P., eds). Marcel Dekker Inc, NY, USA. pp. 141-157

Varanini Z, Pinton R, Behnke HD, Luttge U, Esser K, Kadereit JW, Runge M (1995) Humic substances and plant nutrition. Progress in botany: structural botany, physiology, genetics and taxonomy. Geobotany 56:97-117

Wang CY (1982) Physiological and biochemical responses of plants to chilling stress. HortScience 17(2):173-186

Wilkins MB (1989) Advanced plant physiology. Pitman Publishing Inc, London

Yemm EW, Cocking EC (1955) The determination of amino acids with ninhydrin. Analyst 80:209-213

Zeng K (2002) Effect of dissolved humic substances on the phytochemical degradation rate of - aminopurence and atrazine. J Mol Sci 3:1048-1057

Zhang R, Schmidt E, Zhang XZ (2000) Hormone containing products impact on antioxidant status of tall fescue and creeping betagrass subjected to drought. Crop Sci 40:1344-1349

Zhang W, Wang SY (2001) Antioxidant activity and phenolic compounds in selected herbs. J Agric Food Chem 49:5165-5170

\section{Submit your manuscript to a SpringerOpen ${ }^{\odot}$ journal and benefit from:}

- Convenient online submission

- Rigorous peer review

- Open access: articles freely available online

High visibility within the field

- Retaining the copyright to your article

Submit your next manuscript at $>$ springeropen.com 